Article

\title{
Thiopental and Phenytoin as Novel Ionophores for Potentiometric Determination of Lead (II) Ions
}

\author{
Nashwa M.H. Rizk ${ }^{1,}$, , Samah S. Abbas ${ }^{2}$, Salem M. Hamza ${ }^{3}$ and Yasser M. Abd EL-Karem ${ }^{3}$ \\ ${ }^{1}$ Environmental Biotechnology Department, Genetic Engineering and Biotechnology Research \\ Institute (GEBRI), Minufiya University, Sadat City, Egypt \\ ${ }^{2}$ Pharmaceutical Analytical Chemistry Department, Faculty of Pharmacy, Cairo University, Egypt; \\ E-mail: samah_abbas2005@yahoo.com \\ ${ }^{3}$ Chemistry Department, Faculty of Sciences, Minufiya University, Egypt \\ E-mail: salem.hamza@y.com; yasser_karem_1981@yahoo.com \\ * Author to whom correspondence should be addressed; E-Mail: nashwa05@yahoo.com; \\ Tel.: +20482601267; Fax: +20482601266
}

Received: 20 January 2009; in revised version: 23 February 2009 / Accepted: 9 March 2009 /

Published: 13 March 2009

\begin{abstract}
Two novel polymeric membrane sensors for the analysis of $\mathrm{Pb}(\mathrm{II})$ have been developed based on two therapeutic drugs, thiopental (TP) and phenytoin (PT) as two new ionophores and potassium tetrakis( $p$-chlorophenyl) borate (KTpClPB) as a lipophilic additive, in plasticized PVC membranes. The sensors show a Nernstian response for $\mathrm{Pb}$ (II) ions over the wide concentration ranges of $1 \times 10^{-2}-7 \times 10^{-6} \mathrm{M}$ and $1 \times 10^{-2}-8 \times 10^{-6} \mathrm{M}$ for the sensors based on thiopental and phenytoin, respectively. The proposed sensors have a fast response time and can be used for more than nine weeks without any considerable divergence in potentials. The sensors exhibit comparatively good selectivity with respect to alkaline, alkaline earth and some transition and heavy metal ions. They were employed for direct determination of lead in solder alloys and in galena rocks with a good agreement with the obtained results by atomic absorption spectroscopy.
\end{abstract}

Keywords: Lead (II), Thiopental, Phenytoin, Galena rocks, Solder alloys. 


\section{Introduction}

Lead is an environmental pollutant that accumulates with toxic effects in blood, liver, kidney and in the central nervous system of exposed mammals. The neurotoxicity of lead is of special interest, since cognitive and motor deficits in children have been associated with low levels of lead exposure [1,2]. The nephrotoxicity of lead has also been extensively studied, since the initial accumulation of absorbed lead occurs primarily in the kidney, where it may cause proximal tubular dysfunction after acute exposure, or irreversible nephropathy that may lead to renal failure after chronic exposure [1].

Assessment of accumulation, deficiency and concentration of lead levels require sensitive, reproducible and accurate analytical techniques. Methods in current use for lead quantification include stripping voltammetric-potentiometric electrodes [3,4], hydride generation-ICP OES [5], isotope dilution inductively coupled plasma mass spectrometry [6], electrothermal atomization laser excited atomic fluorescence [7], atomic absorption spectrometry [8-10], voltammetry [11,12], spectrophotometry [13], coulometry [14], and potentiometric methods [15-19].

Bis(2-hydroxyacetophenone)ethylenediimine $\quad[20], \quad N, N^{\prime}$-bis(2-hydroxy-1-napthalene)-2,6pyridinamine [21], $N, N^{\prime}$-dibenzyl-1,4,10,13-tetraoxa-7,16-diazacyclooctadecane [22], piroxicam [23], dioxamides [24,25], 9,10-anthraquinone derivatives [26], derivatized tetrapyrazole and calix[4]arene receptors [27], monobis- and pentakis-derivatives of p-tert-butylcalixarene [28,29], calixarene phosphine oxide derivatives [30], 4-tert-butylcalix[4]arene [31], calix[4]arene amide [32], some fatty acids [33], 3,6-dioxaoctanedithioamide [34], a crown ether [35], a thiacrown derivative [36], a substituted diaza-18-crown-6 [37], tetrabenzy1 pyrophosphate and diphenylphosphinic anhydride [38], a Schiff's base complex [39] and methoxy substituted arylenevinylene derivatives [40] are used as electroactive materials in lead (II) selective membrane sensors. Advantages and limitations of some of these sensors are discussed in this work.

Thiopental (also called pentothal, Figure 1), a thiobarbiturate, is used for the induction of anesthesia prior to the use of other general anesthetic agents and for short surgical, diagnostic, or therapeutic procedures associated with minimal painful stimuli. It is an ultrashort-acting depressant of the central nervous system which induces hypnosis and anesthesia [41]. This drug is also used in the induction phase of general anesthesia, because of how quickly it takes effect. It usually takes less than 30 seconds for the drug to reach the brain and cause unconsciousness. It is not used for prolonged anaesthesia due to the excessive amount of time it takes for the patient to regain consciousness after induction. Instead, inhaled agents are used so that moments after the inhaled agent is removed, the patient regains consciousness [42].

Phenytoin (5,5-diphenylimidazolidine-2,4-dione, Figure 1) is a commonly used antiepileptic. Barbiturates are widely used as sedative hypnotic drugs in a wide variety of conditions and are also employed to produce anesthesia [43]. Phenytoin is one of the cyclic ureides which related in structure to the barbiturates. It was reported to be the least hypnotic, most strongly anticonvulsant and most effective against grand mal [43]. Phenytoin is extensively metabolized in the liver to 5-( $p$-hydroxyphenyl)-5-phenylhydantoin and between 60 and $70 \%$ of the administered dose is excreted as free or as a glucuronide conjugate of 5-(p-hydroxyphenyl)-5-phenylhydantoin. Minor metabolises include 5-(3hydroxyphenyl)-5-phenylhydantoin, 3,4-dihydro-3,4-dihydroxyphenytoin, catechol and 3-O-methyl- 
catechol. The plasma half-life varies considerably within the approximate range of 7-60 $\mathrm{h}$ and is dosedependent [42].

Figure 1. Chemical structure of lead (II) ionophores.

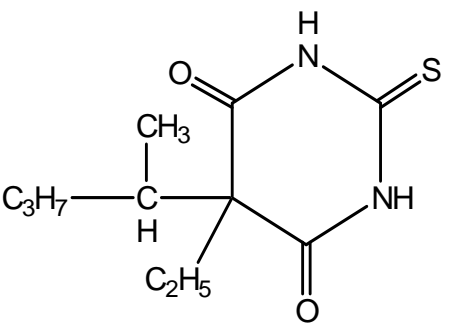

Thiopental

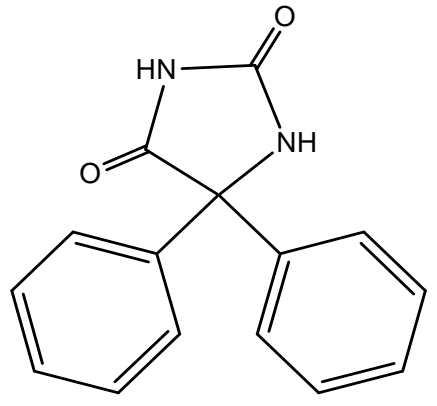

Phenytoin

In this work, new lead sensors incorporating the two ionophores thiopental and phenytoin were used as electroactive materials in a plasticized PVC matrix. These sensors exhibit significantly high sensitivity, stability, selectivity for $\mathrm{Pb}(\mathrm{II})$ ions over many common ions and are successfully used for determining lead (II) ions in various matrices.

\section{Experimental}

\subsection{Equipment}

Potentiometric measurements were made at $25 \pm 1{ }^{\circ} \mathrm{C}$ with an Orion digital ion-analyser (model, 420A) using the proposed sensor with thiopental and phenytoin as ionophores dispersed in PVC matrix and plasticizer as solvent mediator. Lead membranes were used in conjunction with an Orion, $\mathrm{Ag} / \mathrm{AgCl}$ double-junction reference electrode containing $10 \%(\mathrm{w} / \mathrm{v}) \mathrm{KNO}_{3}$ solution in the outer compartment. Adjustment of the $\mathrm{pH}$ was made with an Orion 91-20 combination glass electrode. The cell assembly for the measurement of potential is $\mathrm{Ag} / \mathrm{AgCl} / \mathrm{KCl}(0.1 \mathrm{M}), \mathrm{KNO}_{3} 0.1 \mathrm{M} / \mathrm{sample}$ test solution//sensor membrane//internal filling solution / $\mathrm{AgCl} / \mathrm{Ag}$. Atomic absorption spectrometric measurements of $\mathrm{Pb}^{2+}$ were made with Perkin-Elmer spectrometer (model 3100) using the recommended optimum conditions [44].

\subsection{Reagents}

All chemicals were of analytical-reagent grade, and bidistilled deionized water was used throughout. Thiopental and phenytoin were obtained from Sigma Chemical Co. (St. Louis, MO., USA). $o$-Nitro-phenyloctyl ether (o-NPOE), dioctylphthalate (DOP), and tetrahydrofuran (THF) were obtained from Aldrich Chemical Co. (Milwaukee, Wisconsin, USA). Aqueous $1 \times 10^{-2}-1 \times 10^{-7} \mathrm{M}$ lead solutions were freshly prepared by accurate dilutions of a standard $0.1 \mathrm{M}$ stock lead acetate solution by using $0.01 \mathrm{M}$ acetate buffer of $\mathrm{pH}$ 5.5. 


\subsection{Sensor Construction}

The general procedure for preparation of the PVC membrane is similar to that previously described [16]. The membrane was prepared by mixing $\sim 2 \mathrm{mg}$ portions of thiopental or phenytoin ionophores in a glass Petri dish ( $5 \mathrm{~cm}$ diameter) with $\sim 132 \mathrm{mg}$ of $o$-NPOE and $\sim 66 \mathrm{mg}$ of PVC. The mixture was dissolved in $5 \mathrm{~mL}$ of THF. The Petri dish was covered, and left to stand overnight to allow slow evaporation of the solvent at room temperature. A master PVC membrane $(0.1 \mathrm{~mm}$ thickness) was obtained. The internal reference solution was prepared by mixing equal volumes of $0.01 \mathrm{M} \mathrm{KCl}$ and $\mathrm{Pb}\left(\mathrm{CH}_{3} \mathrm{COO}\right)_{2}$.

\subsection{Calibration of Lead Membrane Sensors}

The membrane sensors were calibrated by immersion in a $1 \times 10^{-7}-1 \times 10^{-2} \mathrm{M}$ lead acetate solution with $0.01 \mathrm{M}$ acetate buffer of $\mathrm{pH}$ 5.5. An aliquot $(1.0 \mathrm{~mL})$ of each solution was transferred into a 50 $\mathrm{mL}$ beaker containing a $0.01 \mathrm{M}$ acetate buffer solution of $\mathrm{pH} 5.5(9 \mathrm{~mL})$. Proposed sensors were immersed and allowed to equilibrate with constant stirring in conjunction with an Orion reference electrode. The sensors were washed with bidistilled deionized water between measurements. The electrode potential was recorded as a function of the lead concentration. The obtained calibration plot was used for subsequent measurements of unknown lead concentration under the same conditions.

\subsection{Sensor Selectivity}

The potentiometric selectivity coefficient $\left(K_{p b(I I), B}^{P o t}\right)$ of the lead sensors was measured by the separate solutions method $[45,46]$. Different concentrations of each interferent and lead solutions $\left(1 \times 10^{-7}-1 \times 10^{-2} \mathrm{M}\right)$ were prepared in $0.01 \mathrm{M}$ acetate buffer of $\mathrm{pH} 5.5$; the potentials were measured and plotted against concentration. The selectivity coefficients were calculated using the following equation:

$$
K_{p b(I I), B}^{P o t}=a_{p b(I I)} /\left(a_{B}\right)^{Z_{P b(I I) / Z} / Z_{B}}
$$

where $\mathrm{a}_{\mathrm{pb}(\mathrm{II})}$ and $\mathrm{a}_{\mathrm{B}}$ are the activities of the primary ion $\mathrm{Pb}^{2+}$ and interfering ion respectively; $\mathrm{Z}_{\mathrm{Pb}(\mathrm{II})}$ and $\mathrm{Z}_{\mathrm{B}}$ are the charges of $\mathrm{Pb}^{2+}$ and interfering ions respectively.

\subsection{Analytical Applications}

\subsubsection{Determination of Lead in Solder Alloys}

About $1.0 \mathrm{~g}$ of sample was added to concentrated nitric acid $(10 \mathrm{~mL})$ until the sample was dissolved, then the solution was diluted by the addition of acetate buffer ( $\mathrm{pH} 5.5,40 \mathrm{~mL}$ ). The $\mathrm{pH}$ was adjusted at $\mathrm{pH} 5.5$ using acetic acid and $\mathrm{NaOH}$. It was then filtered to separate tin. The concentration of lead (II) ions was determined by standard addition methods. Besides, lead in sample solution was 
determined by using atomic absorption spectrometry to compare the results with the potentiometric method.

\subsubsection{Determination of Lead in Rocks}

A well ground portion of galena, a lead ore rock (about $2 \mathrm{~g}$ ) was transferred to a porcelain crucible and digested according to the standard method [47] to convert lead sulfide into lead (II) ions. $\mathrm{K}_{2} \mathrm{~S}_{2} \mathrm{O}_{7}$ (10 g) was added to the rock powder, the components were mixed and the mixture was heated for 30 min on a hot plate. After cooling, a portion of $(1: 1)$ aqueous $\mathrm{HNO}_{3}(60 \mathrm{~mL})$ was added and the crucible was heated on a hot-water bath until the melt disintegrated. The crucible was intermittently shaken, the melt was crushed with a glass rod and the crucible was removed from the water bath. The sample was filtered off, washed with $(1: 1) \mathrm{HNO}_{3}(10 \mathrm{~mL})$ followed by hot distilled water $(50 \mathrm{~mL})$ and the contents were transferred to a $100-\mathrm{mL}$ volumetric flask. The solution was adjusted to the mark with deionized water and shaken. An aliquot of the sample $(1.0 \mathrm{~mL})$ was transferred into a $50 \mathrm{~mL}$ beaker followed by acetate buffer solution of $\mathrm{pH} 5.5(1 \mathrm{~mL})$. The solution was diluted with deionized distilled water to a total volume of $\sim 10 \mathrm{~mL}$ and adjusted to $\mathrm{pH} 5.5$ using acetic acid and $\mathrm{NaOH}$. The lead (II) membrane sensors and a double junction $\mathrm{Ag} / \mathrm{AgCl}$ reference electrode were immersed in the solution and the concentration of $\mathrm{Pb}(\mathrm{II})$ was measured by direct potentiometry. Lead in sample solution was determined by using atomic absorption spectrometry to compare the results with the potentiometric method.

\section{Results and Discussion}

\subsection{Characteristics of the Sensors}

The lead PVC membrane sensors based on the ionophores TP (Sensor 1) and PT (Sensor 2) (see Table 1) with the composition: $\sim 1 \mathrm{wt} . \%$ ionophore, $33 \mathrm{wt} . \%$ PVC and $66 \mathrm{wt} . \%$ plasticizer (o-NPOE) exhibit linear responses to $\mathrm{Pb}^{2+}$ ions within the concentration range of $1 \times 10^{-2}-9 \times 10^{-6} \mathrm{M}$ and $1 \times 10^{-2}$ $1 \times 10^{-5} \mathrm{M}$ with lower detection limits of $7 \times 10^{-6} \mathrm{M}$ and $6.5 \times 10^{-6} \mathrm{M}$, respectively. In the presence of 0.05 wt. $\%$ of KTpCIPB as a membrane additive, and 1 wt.\% ionophore, 33 wt.\% PVC and 66 wt.\% plasticizer (o-NPOE) the detection limit, linear range and calibration slope [48] are improved. The lower detection limits are $5 \times 10^{-6} \mathrm{M}$ and $4.5 \times 10^{-6} \mathrm{M}$ and the linear ranges are $1 \times 10^{-2}-7 \times 10^{-6} \mathrm{M}$ and $1 \times 10^{-2}-8 \times 10^{-6} \mathrm{M}$ for membrane sensors incorporating ionophores TP and PT, respectively. Both sensors exhibit near-Nernstian slope of $31.5 \mathrm{mV}$ per decade (correlation coefficient 0.998 ), and 30.5 $\mathrm{mV}$ per decade (correlation coefficient 0.999$)$, respectively $(\mathrm{n}=6)$.

Lead PVC matrix membrane sensors incorporating ionophore (PT) and different plasticizer having various dielectric constants (e.g. DBS, DOP and $o$-NPOE) were prepared and tested. Membrane sensors based on the PT ionophore (Sensors $8,6,2)$ plasticized with DBS $(\varepsilon=4)$, DOP $(\varepsilon=7)$, and $o$ NPOE $(\varepsilon=24)$ show calibration slops of $21.6,23.6$ and $27.3 \mathrm{mV}$ per decade with linear ranges of $5 \times 10^{-3}-1 \times 10^{-4}, 5 \times 10^{-3}-6 \times 10^{-5}$ and $1 \times 10^{-2}-1 \times 10^{-5}$ and lower detection limits of $8 \times 10^{-5}, 1 \times 10^{-5}$ and $6.5 \times 10^{-6} \mathrm{M}$, respectively. With membrane sensors based on the TP ionophore (Sensors 7, 5, 1), calibration slopes of $22.5,25$ and $28.5 \mathrm{mV}$ per decade with linear ranges of $5 \times 10^{-3}-8.5 \times 10^{-5}, 5 \times 10^{-3}$ - 
$1 \times 10^{-5}$ and $1 \times 10^{-2}-9 \times 10^{-6} \mathrm{M}$ are obtained with DBS, DOP and $o$-NPOE membrane plasticizers, respectively. It can be seen that sensor based on the PT ionophore in a DBS plasticized membrane (Sensor 8) shows lower slope and detection limit, while the sensor based on the TP ionophore in an $o$-NPOE plasticized membrane (Sensor 1) shows higher slope and detection limit. This may be due to the highest dielectric constant of $o$-NPOE than DBS. Table 1 shows the optimization of membranes ingredients of lead sensors based on ionophores (TP) and (PT) with different plasticizers in absence and presence of $\mathrm{KT} \mathrm{CL} \mathrm{PB}$ as a membrane additive.

Table 1. Optimization of membrane ingredients.

\begin{tabular}{cccccccc}
\hline $\begin{array}{c}\text { Sensor } \\
\text { No. }\end{array}$ & Ionophore & PVC & Additive & plasticizer & $\begin{array}{c}\text { Slope } \\
\text { (mV decade }\end{array}$ & $\begin{array}{c}\text { Linear } \\
\text { range } \\
\text { (M) }\end{array}$ & $\begin{array}{c}\text { Lower } \\
\text { detection } \\
\text { limit (M) }\end{array}$ \\
\hline 1 & $2.0(\mathrm{TP})$ & 66.0 & - & $\begin{array}{c}132.0 \\
(o-\mathrm{NPOE})\end{array}$ & 28.5 & $\begin{array}{c}1 \times 10^{-2}- \\
9 \times 10^{-6}\end{array}$ & $7.0 \times 10^{-6}$ \\
\hline 2 & $2.1(\mathrm{PT})$ & 66.1 & - & $\begin{array}{c}131.7 \\
(\mathrm{o}-\mathrm{NPOE})\end{array}$ & 27.3 & $\begin{array}{c}1 \times 10^{-2}- \\
1 \times 10^{-5}\end{array}$ & $6.5 \times 10^{-6}$ \\
\hline 3 & $1.9(\mathrm{TP})$ & 65.9 & $\begin{array}{c}0.1 \\
(\mathrm{KT} p \mathrm{ClPB})\end{array}$ & $\begin{array}{c}132.1 \\
(\mathrm{o}-\mathrm{NPOE})\end{array}$ & 31.5 & $\begin{array}{l}1 \times 10^{-2}- \\
7 \times 10^{-6}\end{array}$ & $5.0 \times 10^{-6}$ \\
\hline 4 & $2.0(\mathrm{PT})$ & 65.7 & $\begin{array}{c}0.1 \\
(\mathrm{KTpClPB})\end{array}$ & $\begin{array}{c}132.0 \\
(\mathrm{o}-\mathrm{NPOE})\end{array}$ & 30.5 & $\begin{array}{l}1 \times 10^{-2}- \\
8 \times 10^{-6}\end{array}$ & $4.5 \times 10^{-6}$ \\
\hline 5 & $1.8(\mathrm{TP})$ & 66.2 & - & $\begin{array}{c}131.8 \\
(\mathrm{DOP})\end{array}$ & 25.0 & $\begin{array}{l}5 \times 10^{-3}- \\
1 \times 10^{-5}\end{array}$ & $8.0 \times 10^{-6}$ \\
\hline 6 & $2.1(\mathrm{PT})$ & 66.0 & - & $\begin{array}{c}132.2 \\
(\mathrm{DOP})\end{array}$ & 23.6 & $\begin{array}{l}5 \times 10^{-3}- \\
6 \times 10^{-5}\end{array}$ & $1.0 \times 10^{-5}$ \\
\hline 7 & $2.0(\mathrm{TP})$ & 66.4 & - & $\begin{array}{c}131.6 \\
(\mathrm{DBS})\end{array}$ & 22.5 & $\begin{array}{l}5 \times 10^{-3}- \\
8.5 \times 10^{-5}\end{array}$ & $4.0 \times 10^{-5}$ \\
\hline 8 & $1.9(\mathrm{PT})$ & 66.1 & - & $\begin{array}{c}132.4 \\
(\mathrm{DBS})\end{array}$ & 21.6 & $\begin{array}{l}5 \times 10^{-3}- \\
1 \times 10^{-4}\end{array}$ & $8.0 \times 10^{-5}$ \\
\hline
\end{tabular}

Table 2 shows the performance characteristics of the lead membrane sensors based on the ionophores TP and PT with $o$-NPOE in presence of KTpClPB. It is well known that the addition of lipophilic ionic sites to an ion-membrane sensor based on a neutral ionophore is necessary to reduce the interference of lipophilic counter-ions, for fast response time, to decrease the electrical resistance of the membrane and to improve the selectivity [46,49]. Calibration slopes of electrode with $0.05 \mathrm{wt} \%$ of potassium tetrakis( $p$-chlorophenyl)borate $(\mathrm{KT}$ pClPB) showed that the electrode has the slope 31.5 $\mathrm{mV}$ per decade for $\mathrm{TP}$ and $30.5 \mathrm{mV}$ per decade for PT. Also the detection limits were improved by using anionic additive (KTpClPB) with the membrane matrix (Table 1). The robustness of an analytical method is a measure of its capacity to remain unaffected by a small but a deliberate variation in method parameters and provide an indication of its reliability during normal usage [50]. While the ruggedness of an analytical method is the degree of the reproducibility at test results obtained by the analysis of the same samples under a variety of conditions such as different laboratories, analysts and instruments [50]. The results obtained by using pH-meter (Orion 420A) were compared with those obtained using another model of $\mathrm{pH}$-meter (Jenway 720). The obtained results are close and also reveal 
the validity of the method. The slight differences in lipophilicity, ring size and polarity of the two ionophores (see Figure 1) do not significantly affect the general electrochemical performances of the sensors (Table 2).

Table 2. Potentiometric response characteristics of $o$-NPOE plasticized PVC membrane sensors with KTpClPB.

\begin{tabular}{|c|c|c|}
\hline Parameter $^{\mathrm{a}}$ & Sensor 3 & Sensor 4 \\
\hline Slope (mV decade $\left.{ }^{-1}\right)$ & 31.5 & 30.5 \\
\hline Intercept (mV) & -330 & -270 \\
\hline Correlation coefficient $(r)(n=6)$ & 0.998 & 0.999 \\
\hline Linear range $(\mathrm{M})$ & $1 \times 10^{-2}-7 \times 10^{-6}$ & $1 \times 10^{-2}-8 \times 10^{-6}$ \\
\hline Lower limit of detection (M) & $5.0 \times 10^{-6}$ & $4.5 \times 10^{-6}$ \\
\hline Response time for $10^{-3} \mathrm{M}(\mathrm{s})$ & $\sim 20$ & $\sim 20$ \\
\hline Working $\mathrm{pH}$ range & $4-7$ & $4-7$ \\
\hline Life span (week) & $>9$ & $>9$ \\
\hline Accuracy $(\%)$ & 99.3 & 99.0 \\
\hline Standard deviation (\%) & 0.7 & 0.6 \\
\hline Repeatability $\left(\mathrm{CV}_{\mathbf{w}} \%\right)$ & 0.8 & 0.7 \\
\hline between day variability $\left(\mathrm{CV}_{\mathbf{b}} \%\right)$ & 0.9 & 1.0 \\
\hline Robustness $^{\mathrm{b}}$ & $101.4 \pm 1.7$ & $102.0 \pm 1.2$ \\
\hline Ruggedness ${ }^{\mathrm{c}}$ & $100.6 \pm 1.5$ & $101.7 \pm 1.6$ \\
\hline
\end{tabular}

The suggested mechanism for the proposed lead (II) ionophores is as follows: the lead forms a stable five membered chelating ring with thiopental and phenytoin in a 1:2 lead (II) to drug ratio. The mechanism was proven by applying Job's method, which is an extremely versatile approach to the determination of reaction stoichiometries [51].

The dynamic response times of sensors based on the TP and PT ionophores with $o$-NPOE in the presence of KTpC1PB to reach $\sim 95 \%$ of equilibrium response are $\sim 20 \mathrm{~s}$ for both sensors. In general the TP and PT ionophore-based based sensors exhibit similar responses characteristics for $\mathrm{Pb}^{2+}$ ions. The response time of the concentrations from $1 \times 10^{-5}$ to $1 \times 10^{-2}$ varies between $15-20 \mathrm{~s}$. The nearly identical response time on varying the metal ion concentration is probably due to the fast exchange kinetics of complexation-decomplexation of $\mathrm{Pb}^{2+}$ ion at the test solution/membrane interface.

The lifetime of the sensors was detected by measuring the slope of the potential versus lead ion concentration over the concentration range of $1 \times 10^{-5}-1 \times 10^{-2} \mathrm{M}$ each week over a period of nine weeks 
while the electrode was in continual use. The slope remained constant through the assessment period. However, a slight change in the response was found and corrected by reconditioning the electrode by soaking it in a $0.01 \mathrm{M}$ solution of $\mathrm{Pb}\left(\mathrm{CH}_{3} \mathrm{COO}\right)_{2}$ for $24 \mathrm{~h}$. The sensors long lifetime are due to that, the ionophore is well soluble in the membrane matrix and the stable complex formation between lead ions and suggested ionophores.

\subsection{Effect of $\mathrm{pH}$ and Foreign Ions}

A study of the potential-pH curves of $\mathrm{Pb}^{2+}$ membrane sensors based on TP and PT ionophores reveals that within the range 4.0-7.0, the potential did not vary by more than $\pm 2 \mathrm{mV}$. At $\mathrm{pH}>7$, the emf values of both sensors sharply decrease due to the precipitation of $\mathrm{Pb}(\mathrm{OH})_{2}$ and/or formation of hydroxyl lead complexes and competition of $\mathrm{OH}^{-}$ion with the ionophores for $\mathrm{Pb}^{2+}$ ions. At $\mathrm{pH}<4$, interferences from $\mathrm{H}^{+}$ions are significant with subsequent increasing in the potential response. All subsequent potentiometric measurements of $\mathrm{Pb}^{2+}$ ions were made in $10^{-2} \mathrm{M}$ acetate buffer background of pH 5.5 (Figure 2).

Figure 2. Effect of the $\mathrm{pH}$ on the potential responses of; (A) (PT) sensor with additive and (B) (TP) sensor with additive at $(\diamond) 1.0 \times 10^{-2} \mathrm{M}$ and $(\boldsymbol{\Delta}) 1.0 \times 10^{-3} \mathrm{M}$ lead concentration.
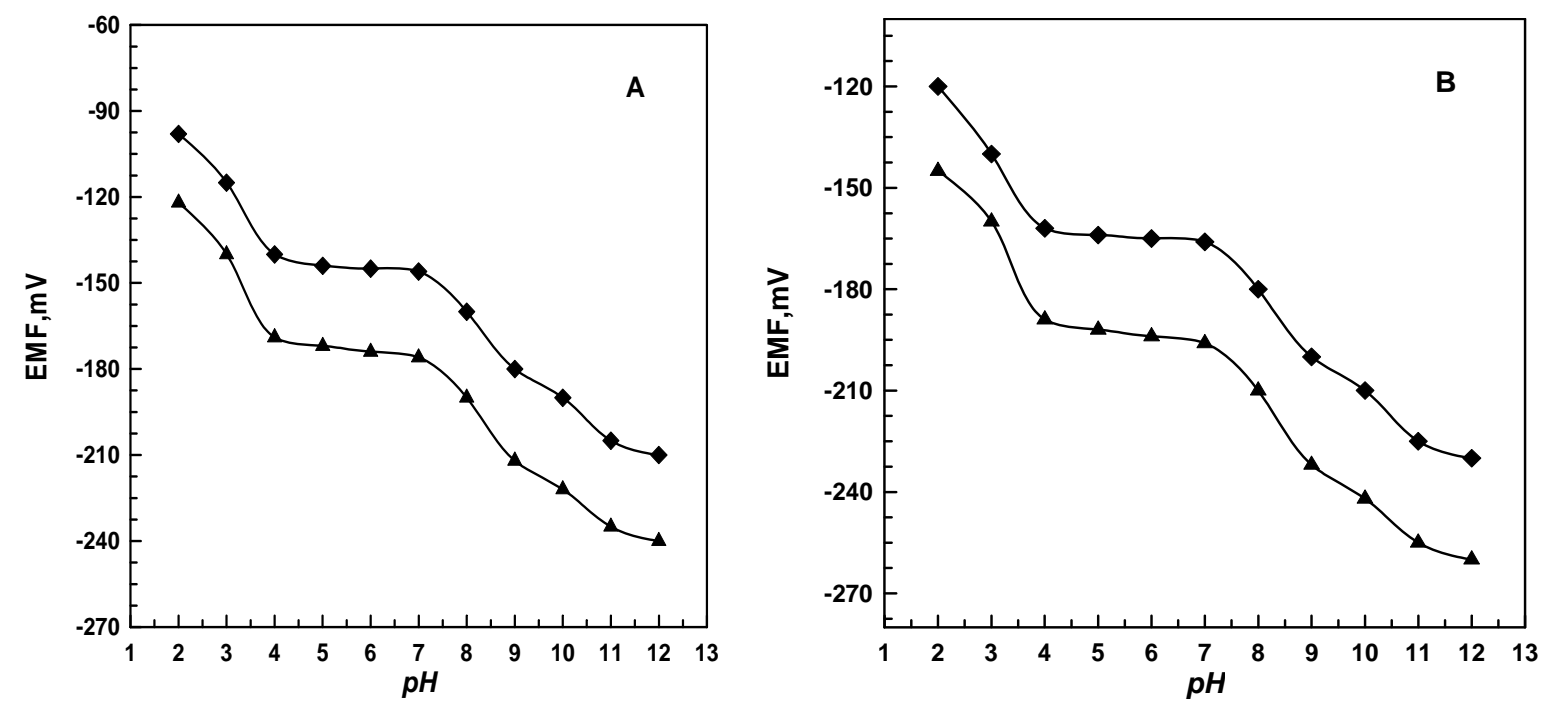

The potentiometric selectivity coefficients $\left(K_{p b(I I), B}^{P o t}\right)$ of lead sensors using KTpCIPB based on TP (Figure 3) and PT (Figure 4) (o-NPOE plasticizer) were determined using the separate solutions (SSM) method $[45,46]$. Another assembles of sensors were used for selectivity determinations rather than that used for $\mathrm{pH}$ measurements. Then different concentrations of each interferent and lead solutions $\left(1 \times 10^{-}\right.$ ${ }^{7}-1 \times 10^{-2} \mathrm{M}$ ) were prepared in $0.01 \mathrm{M}$ acetate buffer of $\mathrm{pH} 5.5$; the potentials were measured and plotted against concentration. The results reveal that high concentrations of most cations do not affect the selectivity of the sensors towards $\mathrm{Pb}^{2+}$ ions. In presence of $\mathrm{KT}$ T CIPB as anionic additive the selectivity of lead sensors were improved more than without additive. This means that the coordination of lead (II) ions by the ionophores can also be related to the presence or the absence of lipophilic anionic sites, which is usually added to such membranes. 
The stability of complexes is governed by the $\mathrm{pH}$ of the metal solutions for $\mathrm{Ca}^{2+}, \mathrm{Sr}^{2+}$ and $\mathrm{Mg}^{2+}$; form stable complexes at $\mathrm{pH} 8-10 . \mathrm{Fe}^{2+}$ form stable complexes in acidic medium. Metals; $\mathrm{Na}^{+}$and $\mathrm{K}^{+}$ can not form stable complexes, while $\mathrm{Al}^{3+}$ can react slowly and form weak complexes. Lead (II) ion can form stable complex over some other heavy metals [52]. The selectivity studies of lead (II) membrane sensors emphasis the superiority of the sensors towards lead (II) over many other metals.

Figure 3. Potentiometric responses of lead membrane sensors based on (TP) with additive as ionophore toward several metal ions.
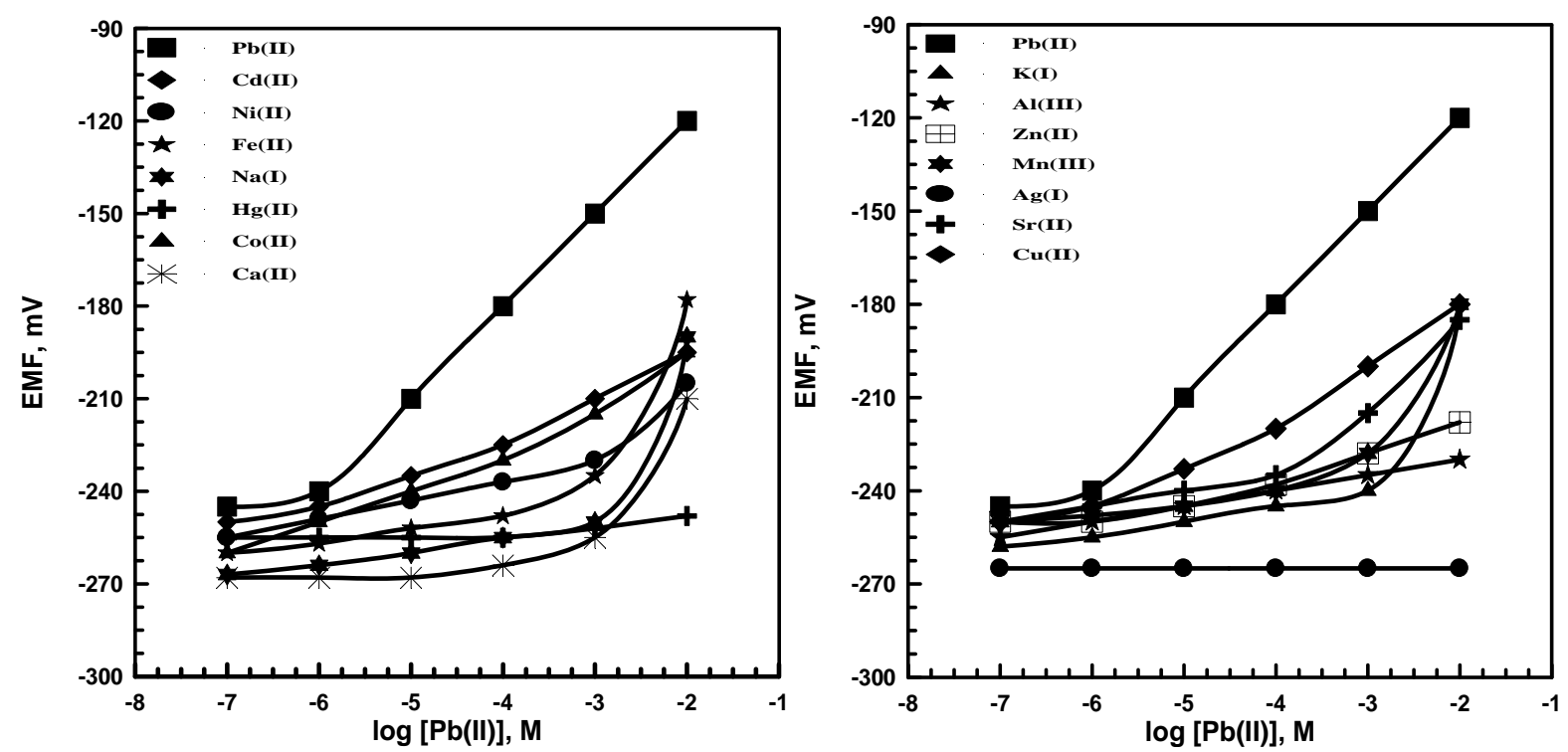

Figure 4. Potentiometric responses of lead membrane sensors based on (PT) with additive as ionophore toward several metal ions.
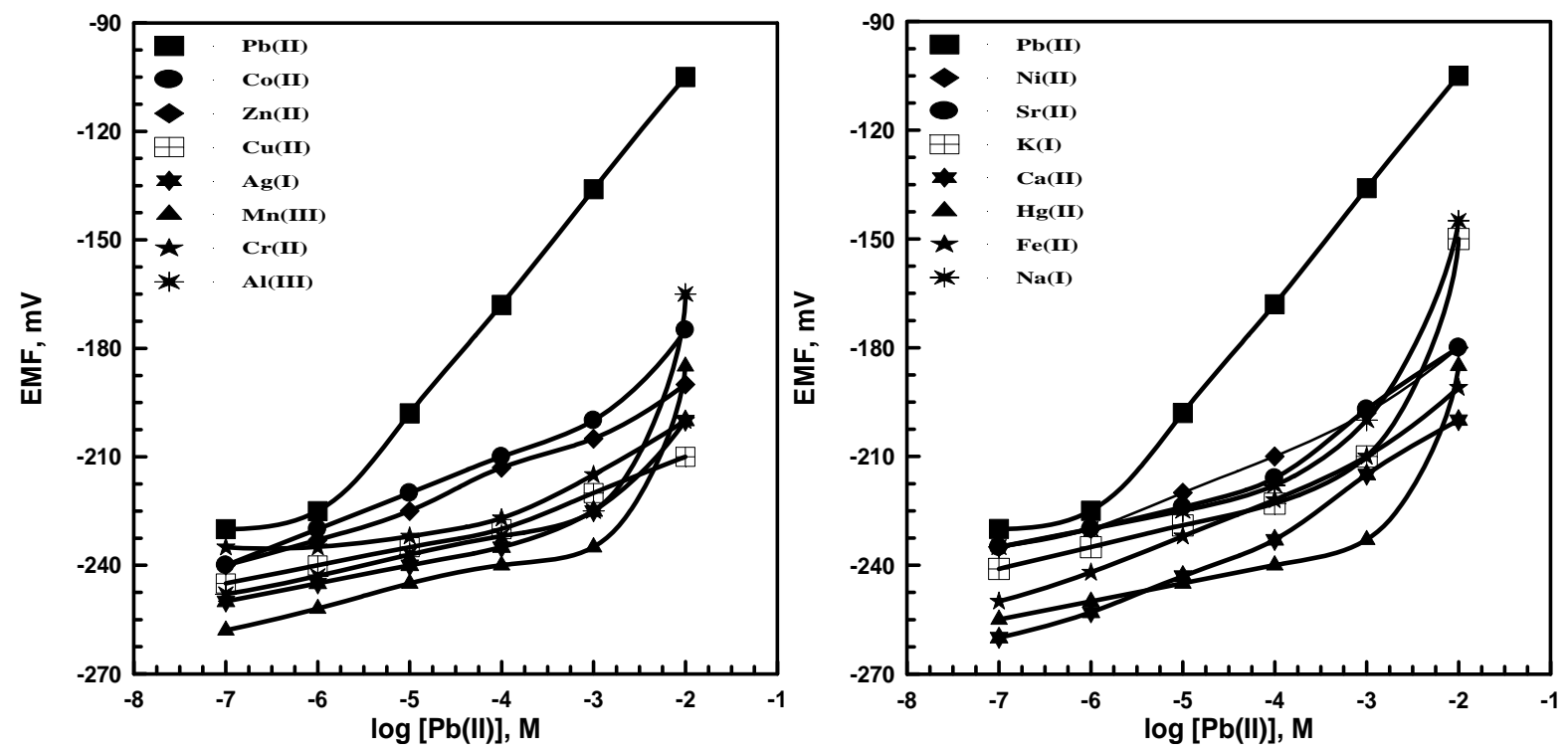

Table 3 represents the selectivity coefficients of PT and TP based lead sensors with and without additives at $10^{-3} \mathrm{M}$ of lead ions and interferent. Membrane sensor based on TP and in presence of additive exhibits slightly better selectivity for $\mathrm{Pb}^{2+}$ ions over metal cations compared to other sensors. 
Table 3. Selectivity coefficient $\left(K_{p b(I I), B}^{P o t}\right)$ of Lead sensors based on PT and TP as ionophores at $10^{-3} \mathrm{M}$ for both $\mathrm{Pb}^{2+}$ and interferent.

\begin{tabular}{|c|c|c|c|c|}
\hline \multirow{2}{*}{ Interfering ion ${ }^{a}$} & \multicolumn{4}{|c|}{$\log K_{p b(I I), B}^{P o t}$} \\
\hline & $\begin{array}{c}\text { TP without } \\
\text { additives }\end{array}$ & $\begin{array}{c}\text { TP with } \\
\text { additives }\end{array}$ & $\begin{array}{c}\text { PT without } \\
\text { additives }\end{array}$ & $\begin{array}{c}\text { PT with } \\
\text { additives }\end{array}$ \\
\hline $\mathrm{Co}^{2+}$ & -2.06 & -3.17 & -2.01 & -2.16 \\
\hline $\mathrm{Hg}^{2+}$ & -1.17 & -1.5 & -1.07 & -1.37 \\
\hline $\mathrm{Ca}^{2+}$ & -2.77 & -5.0 & -2.12 & -4.19 \\
\hline $\mathrm{Sr}^{2+}$ & -2.17 & -3.96 & -2.4 & -3.12 \\
\hline $\mathrm{Zn}^{2+}$ & -2.31 & -2.38 & -2.27 & -2.83 \\
\hline $\mathrm{Cu}^{2+}$ & -1.06 & -1.58 & -1.01 & -1.53 \\
\hline $\mathrm{Mn}^{2+}$ & -2.17 & -3.34 & -3.14 & -3.52 \\
\hline $\mathrm{Ag}^{+}$ & -2.0 & -2.52 & -2.0 & -2.69 \\
\hline $\mathrm{Na}^{+}$ & -3.86 & -5.36 & -3.51 & -3.67 \\
\hline $\mathrm{K}^{+}$ & -3.1 & -4.66 & -3.3 & -3.9 \\
\hline $\mathrm{Fe}^{2+}$ & -2.52 & -3.62 & -2.67 & -3.34 \\
\hline $\mathrm{Al}^{3+}$ & -2.67 & -3.0 & -3.35 & -4.33 \\
\hline $\mathrm{Ni}^{2+}$ & -1.68 & -2.34 & -1.85 & -2.06 \\
\hline $\mathrm{Cd}^{2+}$ & -2.33 & -2.37 & -1.34 & -2.03 \\
\hline
\end{tabular}

${ }^{\mathrm{a}}$ Mean of five measurements

\subsection{Comparison with Other Reported Lead Sensors}

In Table 4, the response characteristics and the selectivity coefficients of the proposed sensors towards some potential interfering ions are compared with corresponding values previously reported for lead ion-selective membrane sensors based on a variety of different ionophores [16,22-24,33,36,39,40]. As can be seen, the linear range and the response time of the proposed sensors are superior to some of those reported for other lead ion-selective membrane sensors and the selectivity's behaviors are among the most selective $\mathrm{Pb}^{2+}$ ion sensor reported. The superiority of TP and PT ionophores over some of other reported ionophores for lead (II) is attributed to the high stability of their lead (II) complexes. 
Table 4. General performance characteristics of some potentiometric lead membrane sensors.

\begin{tabular}{|c|c|c|c|c|c|}
\hline Ionophore & $\begin{array}{l}\text { Linear } \\
\text { Range (M) }\end{array}$ & $\begin{array}{l}\text { Lower } \\
\text { limit of } \\
\text { detection (M) }\end{array}$ & $\begin{array}{l}\text { Slope } \\
\text { (mV/decade) }\end{array}$ & Interferent (M, Selectivity) & Ref. \\
\hline 9,10-Anthraquinone derivatives & $1 \times 10^{-6}-1 \times 10^{-2}$ & $6.7 \times 10^{-7}$ & 28.9 & $\mathrm{Zn}^{2+}, \mathrm{Cd}^{2+}$ & {$[22]$} \\
\hline $\begin{array}{l}\text { Methoxy substituted arylenevinylene } \\
\text { derivatives }\end{array}$ & $4.2 \times 10^{-4}-2.0 \times 10^{-2}$ & $\mathrm{NR}$ & $33-36$ & $\begin{array}{l}\mathrm{Na}^{+}-1.33, \mathrm{~K}^{+}-1.66, \mathrm{Mg}^{2+}-1.3 \\
\mathrm{Zn}^{2+}-1.3, \mathrm{Cd}^{2+}-1.28, \mathrm{Ca}^{2+}-1.39 \\
\mathrm{Cu}^{2+}-0.17, \mathrm{Ni}^{2+}-1.11\end{array}$ & {$[40]$} \\
\hline Dioxamide & $1 \times 10^{-6}-8.4 \times 10^{-3}$ & NR & 31.9 & $\mathrm{Hg}^{2+}-1.6, \mathrm{Fe}^{2+}-1.67, \mathrm{Cd}^{2+}-2.1$ & {$[24]$} \\
\hline Thia crowm derivatives & $1 \times 10^{-6}-8 \times 10^{-3}$ & $8 \times 10^{-7}$ & 29 & $\mathrm{Hg}^{2+}-2.1$ & {$[36]$} \\
\hline Piroxicam & $1 \times 10^{-5}-1 \times 10^{-2}$ & $4 \times 10^{-6}$ & 30 & $\begin{array}{l}\mathrm{UO}^{2+}-0.43, \mathrm{Ag}^{+}-1.2 . \mathrm{K}^{+}-1.29 \\
\mathrm{Zn}^{2+}-1.08, \mathrm{Mg}^{2+}-1.24\end{array}$ & [23] \\
\hline$N, N^{\prime}$-bis(salicylidene)-2,6-pyridinediamine & NR & $9.12 \times 10^{-7}$ & 29.4 & $\begin{array}{l}\mathrm{Na}^{+}-2.5, \mathrm{~K}^{+}-2.2, \mathrm{Ag}^{+}-2.2 \\
\mathrm{Zn}^{2+}-4.1, \mathrm{Co}^{2+}-4.2, \mathrm{Mg}^{2+}-4.9 \\
\mathrm{Cu}^{2+}-2.7\end{array}$ & [39] \\
\hline \multirow[t]{3}{*}{$\begin{array}{l}\text { Chiral 2,6-bis-pyridine-carboximide } \\
\text { derivatives }\end{array}$} & $9 \times 10^{-6}-1 \times 10^{-2}$ & $4.4 \times 10^{-6}$ & 21.6 & $\begin{array}{l}\mathrm{Li}^{+}-3.4, \mathrm{Na}^{+}-3.41, \mathrm{~K}^{+}-3.5 \\
\mathrm{Ca}^{2+}-1.45, \mathrm{Cu}^{2+}-1.06 \\
\mathrm{Cd}^{2+}-1.61, \mathrm{Ag}^{+}-2.89 \\
\mathrm{Hg}^{2+}-1.00\end{array}$ & {$[16]$} \\
\hline & $5.8 \times 10^{-5}-1 \times 10^{-2}$ & $1.8 \times 10^{-5}$ & 33.1 & $\begin{array}{l}\mathrm{Li}^{+}-3.83, \mathrm{Na}^{+}-4.24, \mathrm{~K}^{+}-3.83 \\
\mathrm{Ca}^{2+}-2.14, \mathrm{Cu}^{2+}-2.03 \\
\mathrm{Cd}^{2+}-2.17, \mathrm{Ag}^{+}-2.25 \\
\mathrm{Hg}^{2+}-2.10\end{array}$ & {$[16]$} \\
\hline & $4 \times 10^{-6}-1 \times 10^{-2}$ & $2.1 \times 10^{-6}$ & 25.0 & $\begin{array}{l}\mathrm{Li}^{+}-4.12, \mathrm{Na}^{+}-3.70, \mathrm{~K}^{+}-4.11 \\
\mathrm{Ca}^{2+}-1.91, \mathrm{Cu}^{2+}-1.99 \\
\mathrm{Cd}^{2+}-1.94, \mathrm{Ag}^{+}-2.89, \mathrm{Hg}^{2+}-1.5\end{array}$ & {$[16]$} \\
\hline Fatty acids & $1 \times 10^{-6}-1 \times 10^{-2}$ & NR & 29 & $\mathrm{Ag}^{+}-0.9 . \mathrm{K}^{+}-0.89, \mathrm{Na}^{+}-0.80$ & [33] \\
\hline Thiopental (Sensor 3) & $4.5 \times 10^{-6}-1 \times 10^{-2}$ & $1 \times 10^{-6}$ & 30.5 & $\begin{array}{l}\mathrm{Na}^{+}-3.86, \mathrm{Zn}^{2+}-2.38, \mathrm{Mn}^{2+}-2.17 \\
\mathrm{Cd}^{2+}-1.37, \mathrm{Ag}^{+}-3.52, \mathrm{~K}^{+}-4.66 \\
\mathrm{Ca}^{2+}-3.0, \mathrm{Cu}^{2+}-2.08\end{array}$ & $\begin{array}{l}\text { This } \\
\text { work }\end{array}$ \\
\hline Phenytoin (Sensor 4) & $6.4 \times 10^{-6}-1 \times 10^{-2}$ & $1 \times 10^{-6}$ & 31.5 & $\begin{array}{l}\mathrm{Na}^{+}-3.67, \mathrm{Zn}^{2+}-2.83, \mathrm{Mn}^{2+}-3.52 \\
\mathrm{Cd}^{2+}-1.34, \mathrm{Ag}^{+}-3.0 . \mathrm{K}^{+}-4.19 \\
\mathrm{Ca}^{2+}-1.19, \mathrm{Cu}^{2+}-2.03\end{array}$ & $\begin{array}{l}\text { This } \\
\text { work }\end{array}$ \\
\hline
\end{tabular}

NR, not reported

\subsection{Direct Determination of $\mathrm{Pb}^{2+}$ Ions}

Determination of $\mathrm{Pb}^{2+}$ ions using the TP or PT based ionophore lead sensors was validated according to the quality assurance standards [53]. Five batches $\left(15 \mu \mathrm{g} \mathrm{mL} \mathrm{m}^{-1}\right)$ were used (five determination each) for measuring accuracy, precision, linear range, lower limit of detection, repeatability $\left(\mathrm{CV}_{\mathrm{w}}\right)$ and between-day-variability $\left(\mathrm{CV}_{\mathrm{b}}\right)$. 


\subsection{Analytical Applications}

\subsubsection{Determination of Lead in Solder Alloys}

The sensors based on TP and PT were employed to determine the lead (II) concentration in real samples. Lead is used in a number of alloys, particularly low-melting alloys, such a solder, A commercial solder alloy purchased from Save (Vitoria, Spain), containing mainly lead and tin, was used in this study. Lead in the sample was put into solution by treatment with concentrated nitric acid to dissolve lead and to precipitate tin in acidic media; if concentrated hydrochloric acid was added, the tin would be re-dissolved. Since the aim of this analysis is to determine lead in solder alloys, it is better to remove any tin of the sample solution, In fact, better results, without any tin interference, were obtained when the sample treatment was only made with concentrated nitric acid. The obtained results in Table 5, which have been showed a lead percentages of $70.2 \pm 0.5$ (Sensor 3) and $69.8 \pm 0.4$ in solder alloys. In order to show that potentiometric sensors are suitable to make this determination, the samples were analyzed by atomic absorption spectrometry [8]. The obtained result of lead percentage is $66.9 \pm 0.8$. In this way, lead determination data by the potentiometric method are in good agreement regarding to precision $(\mathrm{F})$ with the obtained results by atomic absorption spectroscopy. But we found significant difference between the proposed and reported [8] methods regarding accuracy (t-test), Table 5.

Table 5. Determination of lead in solder alloy by using potentiometric sensors and atomic absorption spectrometry (AAS) techniques.

\begin{tabular}{cccc}
\hline \multirow{2}{*}{ Sample } & \multicolumn{3}{c}{ Lead content $^{\text {a }}$ (mg/g) } \\
\cline { 2 - 4 } & Sensor 3 & Sensor 4 & AAS [8] \\
\hline 1 & $70.2 \mathrm{mg} \pm 0.5 \mathrm{mg}$ & $69.7 \mathrm{mg} \pm 0.4 \mathrm{mg}$ & $66.7 \mathrm{mg} \pm 0.9 \mathrm{mg}$ \\
& & & \\
2 & $70.0 \mathrm{mg} \pm 0.6 \mathrm{mg}$ & $69.9 \mathrm{mg} \pm 0.5 \mathrm{mg}$ & $66.9 \mathrm{mg} \pm 0.9 \mathrm{mg}$ \\
3 & $70.5 \mathrm{mg} \pm 0.5 \mathrm{mg}$ & $69.9 \mathrm{mg} \pm 0.3 \mathrm{mg}$ & $67.2 \mathrm{mg} \pm 0.8 \mathrm{mg}$ \\
& $\mathrm{F}=1.49$ & $\mathrm{~F}=3.31\left(19^{*}\right)$ & \\
& $\mathrm{t}=17.39$ & $\mathrm{t}=21.1\left(2.77^{*}\right)$ & \\
\hline
\end{tabular}

${ }^{\text {a. }}$ Mean of three measurements; * Tabulated value $(n=3)$.

\subsubsection{Determination of $\mathrm{Pb}^{2+}$ in Galena Rocks}

The lead content of some natural rocks (e.g. galena) was assessed. The rocks were dissolved in nitric acid and the lead (II) solution was measured by direct potentiometry using TP and PT ionophore based membrane sensors. The obtained results by potentiometric sensors in Table 6, which have been showed a lead percentages of $12.5 \pm 0.6$ (Sensor 3) and $12.3 \pm 0.4$ (Sensor 4) in galena rocks. Similar result $(12.5 \pm 0.8)$ was obtained using atomic absorption spectrometry [8]. As can be seen, we found 
from the statistical methods, data in good agreement with reference method regarding accuracy (t-test) and precision ( $\mathrm{F}$ value).

Table 6. Determination of lead in galena rock by using potentiometric sensors and atomic absorption spectrometry (AAS) techniques.

\begin{tabular}{cccc}
\hline Sample & \multicolumn{3}{c}{ Lead content $^{\text {a }}$ (mg/g) } \\
\cline { 2 - 4 } & Sensor 3 & Sensor 4 & AAS [8] \\
\hline 1 & $12.2 \mathrm{mg} \pm 0.8 \mathrm{mg}$ & $12.0 \mathrm{mg} \pm 0.5 \mathrm{mg}$ & $12.5 \mathrm{mg} \pm 0.9 \mathrm{mg}$ \\
& & & \\
2 & $12.7 \mathrm{mg} \pm 0.4 \mathrm{mg}$ & $12.9 \mathrm{mg} \pm 0.2 \mathrm{mg}$ & $12.7 \mathrm{mg} \pm 0.8 \mathrm{mg}$ \\
3 & $12.7 \mathrm{mg} \pm 0.8 \mathrm{mg}$ & $12.1 \mathrm{mg} \pm 0.5 \mathrm{mg}$ & $12.4 \mathrm{mg} \pm 0.7 \mathrm{mg}$ \\
& $\mathrm{F}=6.46$ & $\mathrm{~F}=18.69\left(19^{*}\right)$ \\
$\mathrm{t}=0.222$ & $\mathrm{t}=0.822\left(2.77^{*}\right)$ \\
\hline \multicolumn{4}{c}{${ }^{\mathrm{a} .}$ Mean of three measurements; ${ }^{*}$ Tabulated value $(\mathrm{n}=3)}$.
\end{tabular}

\subsection{Conclusions}

The main advantage of the potentiometric sensor is its simplicity of preparation, short conditioning time, fast response time, Nernstian behavior and improved good selectivity. The membrane is longlived and chemically stable. The sensor was successfully applied to the direct determination of $\mathrm{Pb}$ (II) in solder alloys and galena rocks.

\section{References and Notes}

1. Al-Saleh, I.A.S. The biochemical and clinical consequences of lead poisoning. Med. Res. Rev. 1994, 14, 415-486.

2. Bressler, J.; Kim, K.; Chakraborti, T.; Goldstein, G. Molecular mechanisms of lead neurotoxicity. Neurochem. Res. 1999, 24, 595-600.

3. Xian, Y.; Li, X.; Lian, T.; Zhu, X.; Wang, X. Standardization of urinary lead determination by differential potentiometric-stripping analysis. Gongye Weisheng Yu Zhiyebing 1989, 4, 226-229. (In Chinese)

4. Wang, J.; Tian, B. Screen-printed stripping voltammetric-potentiometric electrodes for decentralized testing of trace lead. Anal. Chem. 1992, 64, 1706-1709.

5. Marrero, J.; Arisnabarreta, S.P.; Smichowski, P. Comparison of effects of four acid oxidant mixtures in the determination of lead in foods and beverages by hydride generation-ICP OES. At. Spectrosc. 2003, 24, 133 -142.

6. Packer, A.P.; Gervasio, A.P.G.; Miranda, C.E.S.; Reis, B.F.; Menegario, A.A.; Giné, M.F. Online electrolytic dissolution for lead determination in high-purity copper by isotope dilution inductively coupled plasma mass spectrometry. Anal. Chim. Acta 2003, 485, 145-153.

7. Le-Bihan, A.; Lijour, Y.; Giamarchi, P.; Burel-Deschamps, L.; Stephan, L. Laser-induced fluorescence with an OPO system. Part II: direct determination of lead content in seawater by 
electrothermal atomization laser excited atomic fluorescence (ETA-LEAF). Anal. Bioanal. Chem. 2003, 375, 815-819.

8. Akman, S.; Tokman, N. Determination of lead and nickel in apple-leaves and sea-water by electrothermal atomic absorption spectrometry after solid-phase extraction using Chromo- sorb107 filled in a syringe. Talanta 2003, 60, 199-204.

9. Ensafi, A.A.; Khayamian, T.; Karbasi, M.H. On-line preconcentration system for lead(II) determination in waste water by atomic absorption spectrometry using active carbon loaded with Pyrogallol Red. Anal. Sci. 2003, 19, 953-956.

10. Nakajima, J.; Hirano, Y.; Oguma, K. Determination of lead in sea water by flow- injection online preconcentration-electrothermal atomic absorption spectrometry after coprecipitation with iron (III) hydroxide. Anal. Sci. 2003, 19, 585-588.

11. Ensafi, A.A.; Khayamian, T.; Atabati, M. Differential pulse cathodic stripping adsorption voltammetric determination of trace amounts of lead using factorial design for optimization. Talanta 2003, 59, 727-733.

12. Hu, C.G.; Wu, K.B.; Dai, X.A.; Hu, S.S. Simultaneous determination of lead(II) and cadmium(II) at a diacetyldioxime modified carbon paste electrode by differential pulse stripping voltammetry. Talanta 2003, 60, 17-24.

13. Li, Z.J.; Chen, Y.P.; Pan, J.M.; Tang, J. The determination of lead in industrial samples by spectrophotometry with 2-(2-sulfophenylazo)-7-(2,6-dibromo-4-methylphenylazo)-1,8-dihydroxynaphthalene-3,6-disulfonic acid. Anal. Lett. 2002, 35, 2157-2171.

14. Demkin, A.M. Coulometric determination of lead (II) and lead (IV) in high Tc superconductors containing copper and bismuth. J. Anal. Chem. 2000, 55, 175-181.

15. Karami, H.; Mousavi, M.F.; Shamsipur, M. Flow injection potentiometry by a new coated graphite ion-selective electrode for the determination of lead ion. Talanta 2003, 60, 775-786.

16. Hassan, S.S.M.; Ghalia, M.H.A.; Amr, G.E.; Mohamed, A.H.K. New lead (II) selective membrane potentiometric sensors based on chiral 2,6-bis- pyridinecarboximide derivatives. Talanta 2003, 1, 81-91.

17. Yaftian, M.F.; Rayati, S.; Emadi, D.; Matt, D. A coated wire-type lead (II) ion selective electrode based on a phosphorylated calix[4]arene derivative. Anal. Sci. 2006, 22, 1075-1078.

18. Kim, H.; Kyoung-Lee, H.; Young-Choi, A.; Jeon, S. Polymeric lead (II)- selective electrode based on N,N'-bis-thiophen-2-ylmethylene-pyridine-2,6- diamine as an ion carrier. Bull. Korean Chem. Soc. 2007, 28, 538-548.

19. Isvoranu, M.; Luca, C.; Pleniceanu, M.; Spinu, C. Stuides on a $\mathrm{Pb}^{2+}$-selective electrode with a macrocyclic liquid membrane. Potentiometric determination of $\mathrm{Pb}^{2+}$. J. Serb. Chem. Soc. 2006, $71,1345-1352$.

20. Ardakani, M.M.; Pourhakak, P.; Niasari, M.S. Bis(2 hydroxyacetophenone) ethylenediimine as a neutral carrier in a coated wire membrane electrode for lead(II). Anal. Sci. 2006, 22, 865-870.

21. Gupta, V.K.; Jain, A.K.; Maheshwari, G. Pb(II) selective sensor based on of N, N'- bis(2hydroxy-1-napthalene)-2,6-pyridiamine in (Polyvinyl) chloride matrix. Int. J. Electrochem. Sci. 2007, 2, 102-112.

22. Gupta, V.K.; Jain, A.K.; Kumar, P. PVC-based membranes of N, N'-dibenzyl-1, 4,10,13-tetraoxa7, 16-diazacyclooctadecane as $\mathrm{Pb}(\mathrm{II})$-selective sensor. Sens. Actuat. B 2006, 120, 259-265. 
23. Sadeghi, S.; Dashti, G.R.; Shamsipur, M.; Lead-selective poly(vinyl chloride) membrane electrode based on piroxicam as a neutral carrier. Sens. Actuat. B 2002, 81, 223-228.

24. Borraccino, A.; Campanella, L.; Sammartino, M.P.; Tomassetti, M.; Battilotti, M. Suitable ion selective sensors for lead and cadmium analysis. Sens.. Actuat. B 1992, 7, 535-539.

25. Lerchi, M.; Bakker, E.; Rusterholz, B.; Simon, W. Lead selective bulk optodes based on neutral ionophores with subnanomolar detection limits. Anal. Chem. 1992, 64, 1534-1540.

26. Barzegar, M.; Mousavi, M.F.; Khajehsharifi, H.; Shamsipur, M.; Sharghi, H. Application of some recently synthesized 9,10 -anthraquinone derivatives as new class of ionophores responsive to lead (II) ion. IEEE Sens. J. 2005, 5, 392-397.

27. Jain, A.K.; Gupta, V.K.; Singh, L.P.; Raisoni, J.R. A comparative study of $\mathrm{Pb}^{2+}$ sensors based on derivatized tetrapyrazole and calix[4]arene receptors. Electrochim. Acta 2006, 51, 2547-2553.

28. Wroblewski, W.; Brzozka, Z. Switching of ion selectivity of membranes by lipophilic ionic sites. Anal. Chim. Acta 1996, 326, 163-168.

29. Buhlmann, P.; Pretsch, E.; Bakker, E. Carrier based ion selective electrodes and bulk optodes. 2. ionophores for potentiometric and optical sensors. Chem. Rev. 1998, 98, 1593-1687.

30. Cadogan, F.; Kan, P.; Mc, Kervey M.A.; Diamond, D. Lead-selective electrodes based on calixarene phosphine oxide derivatives. Anal. Chem. 1999, 71, 5544-5550.

31. Gupta, V.K.; Mangla, R.; Agarwal, S. Pb (II) selective potentiometric sensor based on 4-tertButylcalix[4]arene in PVC matrix. Electroanalysis 2002, 14, 1127- 1132.

32. Chen, L.; Zhang, J.; Zhao, W.; He, X.; Liu, Y. Double-armed calix[4]arene amide derivatives as ionophores for lead ion-selective electrodes. J. Electroanal. Chem. 2006, 589, 106-111.

33. Mousavi, M.F.; Barzegar, M.B.; Sahari, S. A PVC-based capric acid membrane potentiometric sensor for lead (II) ions. Sens. Actuat. B 2001, 73, 199-204.

34. Bakker, E.; Willer, M.; Pretsch, E. Detection limit of ion-selective bulk optodes and corresponding electrodes. Anal. Chim. Acta 1993, 282, 265-271.

35. Srivastava, S.K.; Gupta, V.K.; Jain, S. Determination of lead using poly (vinyl chloride) based crown ether membrane. Analyst 1995, 120, 495-498.

36. Shamsipur, M.; Ganjali, M.R.; Rouhollahi, A. Lead selective membrane potentiometric sensor based on an 18-membered thiacrown derivative. Anal. Sci. 2001, 17, 935-938.

37. Mousavi, M.F.; Sahari, S.; Alizadeh, N.; Shamsipur, M. Lead ion-selective membrane electrode based on 1,10-dibenzyl-1,10-diaza-18-crown-6. Anal. Chim. Acta 2000, 414, 189-194.

38. Xu, D.; Katsu, T. Tetrabenzyl pyrophosphate as a new class of neutral carrier responsive to lead ion. Talanta 2000, 51, 365-371.

39. Jeong, T.; Lee, H.K.; Jeong, D.C.; Jeon, S. A lead(II)-selective PVC membrane based on a Schiff base complex of $N, N$ '-bis(salicylidene)-2,6-pyridinediamine. Talanta 2005, 65, 543-548.

40. Zimkus, A.; Cretscu, I.; Grzybowska, I.; Radecka, H.; Geise, H.J.; Dieltiens, P.; Aleksandrzak, K. Potentiometric lead (II) ions recognition by liquid membrane electrodes incorporating methoxy substituted arylenevinylene derivatives. Pol. J. Environ. Stud. 2003, 12, 773-778.

41. Arain, S.R.; Navani, A.; Ebert, T.J. The effects of thiopental and generic and nongeneric propofol on respiratory resistance during anesthetic induction in patients with reactive airways. J. Clin. Anesth. 2002, 14, 257-261. 
42. Moffat, A.C.; Jackson, J.V.; Moss, M.S.; Widdop, B.; Greenfield, E.S. Clarke's Isolation and Identification of Drugs, $2^{\text {nd }}$ Ed; The Pharmaceutical Press: London, U.K., 1986.

43. Saleh, G.A. Charge-transfer complexes of barbiturates and phenytoin. Talanta 1998, 46, 111-121.

44. Hassan, S.S.M. Organic Analysis Using Atomic Absorption Spectrometry, Ellis Horwood: Chichester, U.K., 1984.

45. Hassan, S.S.M.; Elnemma, E.M.; Mohamed, A.H.K. Novel potentiometric copper (II) selective membrane sensors based on tetrapeptide derivatives as neutral ionophores. Talanta 2005, 66, 1034-1041.

46. Umezawa, Y.; Buhlmann, P.; Umezawa, K.; Tohda, K.; Amemiya, S. Potentiometric selectivity coefficients of ion-selective electrodes, part I. inorganic cations. Pure Appl. Chem. 2000, 72, 1851-2082.

47. Vanloon, J.C.; Barefoot, R.R. Analytical Methods for Geochemical Exploration Textbook. University of Toronto: Toronto, ON, Canada, 1989.

48. Buck, P.R.; Coşofret, V.V. Recommended procedures for calibration of ion-selective electrodes. Pure Appl. Chem. 1993, 65, 1849-1858.

49. Ammann, D.; Pretsch, E.; Simon, W.; Lindler, E.; Bezegh ,A.; Pungor, E. Lipophilic salts as membrane additives and their influence on the properties of macro- and micro-electrodes based on neutral carriers. Anal. Chim. Acta 1985, 171, 119-129.

50. The United States Phamacopeia/National Formulary 2007, $25^{\text {th }}$ Ed.; United States Pharmacopeial Convention: Rockville, MD, USA, 2007.

51. Rose, J. Advanced Physico Chemical Experiments; Sir Issac Pitman and Sons Ltd.: London, U.K., 1964.

52. Francisco, J.O.; Janick, F.A.; Raina, M.M. Stability constants for the complexation of various metals with a rhamnolipid biosurfactant. J. Environ. Qual. 2001, 30, 479-485.

53. Taylor, J. K. Quality Assurance of Chemical Measurements. Lewis Publishers CRC Press: Chelsea, MI, USA, 1987.

(C) 2009 by the authors; licensee Molecular Diversity Preservation International, Basel, Switzerland. This article is an open-access article distributed under the terms and conditions of the Creative Commons Attribution license (http://creativecommons.org/licenses/by/3.0/). 